\title{
The Lists of Alexander von Humboldt: On the Epistemology of Scientific Practice
}

\author{
Ottmar Ette
}

\section{The Epistemologist's Laughter}

Together, a list and laughter gave rise to perhaps the most well-known book on contemporary epistemology. The first paragraph of the preface in Les mots et les choses is filled with and famously makes reference to the imaginative power of literature:

This book first arose out of a passage in Borges, out of the laughter that shattered, as I read the passage, all the familiar landmarks of my thought our thought, the thought that bears the stamp of our age and our geography - breaking up all the ordered surfaces and all the planes with which we are accustomed to tame the wild profusion of existing things, and continuing long afterwards to disturb and threaten with collapse our age-old distinction between the Same and the Other. This passage quotes a 'certain Chinese encyclopedia' in which it is written that 'animals are divided into: (a) belonging to the Emperor, (b) embalmed, (c) tame, (d) sucking pigs, (e)

O. Ette $(\bowtie)$

University of Potsdam, Potsdam, Germany

e-mail: ette@uni-potsdam.de

(C) The Author(s) 2022

R. A. Barton et al. (eds.), Forms of List-Making: Epistemic, Literary, and Visual Enumeration, https://doi.org/10.1007/978-3-030-76970-3_5 
sirens, (f) fabulous, (g) stray dogs, (h) included in the present classification, (i) frenzied, (j) innumerable, $(\mathrm{k})$ drawn with a very fine camelhair brush, (1) et cetera, $(\mathrm{m})$ having just broken the water pitcher, $(\mathrm{n})$ that from a long way off look like flies'. In the wonderment of this taxonomy, the thing we apprehend in one great leap, the thing that, by means of the fable, is demonstrated as the exotic charm of another system of thought, is the limitation of our own, the stark impossibility of thinking that. (Foucault 1970, XV)

In Les mots (first published in 1966 by Gallimard) Michel Foucault opts not only for a literary text as a launching point for his "archaeology of the human sciences," but also begins with the Argentinean Jorge Luis Borges, a representative of that particular brand of Latin American literature which, during the 1960s, experienced a dramatic ascension to worldwide renown. In doing so, he of course did not select a text which could be categorized as belonging to the authors of the so-called boom in Latin American literature, but rather a text from that Argentinean who would soon be considered one of the primary references and forerunners for what is generally regarded as "postmodernism." After a several decadelong delay Borges would grow to be esteemed as its founder within the Western order of world literature. His laughter over such classifications and categorizations is certainly understandable.

The matter of situating Michel Foucault within structuralism or poststructuralism, within modernism or postmodernism, rather than opening the door for any serious reflection, serves as a reminder that such "alternatives" ought to be regarded as case-in-point evidence of a striking lexical and conceptual deficiency. Still, it is worth highlighting that Foucault meditates on the breaking up of "the thought that bears the stamp of our age" $(1970, \mathrm{XV})$ and, in doing so, introduces a spatial-temporal limitation traversing millennia of occidental thought and history, which undoubtedly constitutes Foucault's intention when he writes of our thought, for the relationship between words and objects which he examines is evidently one which bears with it such spatial-temporal restrictions.

Accordingly, it is the epistemologist's laughter which is situated at the heart of the initial excerpt from Les mots and les choses-a downright Rabelaisian cackle in the face of cognitive limits, which literature may well be able trace out and perhaps even grasp by means of artifice but which now prove (categorically, at least) unfathomable for Western philosophy. And at the crux of Foucault's interest is the "impossibility of thinking 
that" (1970, XV). But what precisely is that which has been designated as impossible to think?

At the center of Borges" "The Analytical Language of John Wilkins" (as cited by Foucault) is a list which is subdivided into thirteen cataloged points. This list proves unintelligible, owing to "our age-old distinction between the Same and the Other" (Foucault 1970, XV). In other words, it cannot be conceived of on epistemological grounds. Following the French philosopher Vincent Descombes, it is clear that a significant part of the history of twentieth-century French philosophy can be regarded of in terms of these two concepts as a history revolving around le même and l'autre (see Descombes 1981). It is this (occidental) episteme to which Foucault refers as he begins his preface.

Suppose it were the case that this episteme precluded the possibility of our comprehending Borges' thirteen-item long list. As a corollary, of course, it would not follow that the individual entries be generally unintelligible. Rather, it would simply be the case that they cannot be conceived in terms of one and the same logic. Hence, what is required is either a different logic to understand Borges' list or a composite of disparate and diverse logics, a multilogical thought structure from which various divisions and subdivisions might be conceived of. Literature-including world literatures-circumvents such complications. It represents such a multilogical system.

Upon closer examination of the list, the chinoiserie as recounted by Borges, we find that it contains a small list embedded within it. The first point consists of a kind of mise en abyme, designated here by a formulaic expression for lists- “and so on"-which, as a general rule, tends toward infinity. It thus contains, as it were, the entire list in the form of pars pro toto, in which we may detect the ars pro toto and the Argentinean's pleasure associated with it. For the formula "etc." or "et cetera" opens up the possibility of expanding a given list and, if necessary, of permitting it to grow on into a limitless list of endless indulgence and boundless delight.

Yet the epistemologist's laughter is more likely about the occidental impossibility of thinking of this multilogical list. Is it laughter arising out of perplexity or rather laughter accepting a challenge? At the same time, it denotes the point at which, in the face of a list, the acknowledgment of a historical burden is broken, an acknowledgment which, of course, on a meta-level, releases that pleasure which is able to find expression in the form of laughter. If we allow this pleasure space, it does not, in the face of the historical burden, remain fixed in place to deny further service. Rather, 
it gives rise to certain lists which make it possible to contemplate the task that the list of conceivable animals poses. Delight sets the lists in motion, as it were.

The Borgesian text offers a glimpse into the epistemology of et cetera. Indeed, it would be conceivable, given the possibilities of our thought, to open the invitation received in Borges' text to a praise of "and so on," to a eulogy of "et cetera," thereby conceiving of an epistemology of widening and expansion existing beyond Foucault's laughter (see Ette 2016). But our task in the following deliberations is not aimed at altering the occidental episteme, but rather at exploring the thinking of one of the main representatives of science grounded in that episteme, whose 250th birthday we celebrate this year.

\section{The Emergence of the Humboldtian Science}

Let us begin with a factual statement: There are hundreds, indeed, thousands of lists and enumerations throughout the entirety of Alexander von Humboldt's scientific works. If we hope to achieve an overview of the thinking, writing, and scientific style of the Prussian natural and cultural scientist, ${ }^{2}$ his Amerikanische Reisetagebücher offer a most promising starting point, for they have come to stand for something along the lines of the birth certificate, the record of origin for the Humboldtian science. And even within them, the distinction between practical and poetic lists, as introduced by Umberto Eco, proves hardly pertinent (see Eco 2009, 113). For it was not only in his Ansichten der Natur that Alexander von Humboldt sought to harmonize literary aims with purely scientific ones ${ }^{3}$ : in his printed works as well as in his manuscripts, both fields flow into one another again and again.

One would be hard-pressed to find any document or text which bears such precise traces of the lengthy and sometimes arduous process which marked the rise of the science for which the younger of the two Humboldt brothers with all his personality was responsible. They constitute the true core and, at the same time, the biography of the academic and author who recorded hypotheses, measurements, observations and insights in his Amerikanische Reisetagebücher not only during his voyage through the American tropics, but over a period of almost seven decades. They thus accompanied him throughout his entire life and serve as a testimony to the development of the transdisciplinary work which has come to be associated with the name Humboldt. 
In order to recognize the significance of these travel manuscripts, it is important for the contemporary reader to bear in mind that, with the onset of his journey to America in 1799, Humboldt was rounding off the first of three phases of his life and entering the second, much more selfdetermined phase. Born in Berlin beneath the blessing of a comet in 1769 , Humboldt spent the first nearly thirty years of his life as a self-proclaimed "nomad," as a "stranger" amongst the sciences. ${ }^{4}$ He had traversed the most disparate of disciplines from chemistry and mathematics to botany and geography all the way to history and cameralistics, which he had studied on the "frosty banks of the Oder" at the Viadrina in Frankfurt an der Oder. A long list of subjects, indeed.

The youthful Humboldt had-at times in succession, at times simultaneously-busied himself with myriad and diverse disciplines, further expanding the horizons of his knowledge at the University of Göttingen in anthropology, philology, and surely in philosophy as well. Complementing this was his time at the Commercial Academy in Hamburg where he continued to refine his knowledge in cameralistics. He completed his studies in mining technology in the famous Saxon town of Freiberg in one-third of the normal period of study and proceeded to embark on a career in the Prussian mining service. There he quickly experienced a rapid rise from prospective mining assessor to government mining official. But Humboldt had his sights set on higher things.

For after the death of his mother he unceremoniously turned his back on Prussia and turned his inheritance into tinkling coins, which he would then be able to use for a planned and long-desired trip to non-European regions. After several false starts, his voyage from 1799-1804 through the Spanish colonial regions of America - a journey through today's Venezuela, Cuba, Colombia, Ecuador, Peru, Mexico, again Cuba and the United States-would ultimately transform him into an international star in the scientific community. He quickly began acquiring membership status in both national and international academies alike. Humboldt had long since given up compiling an unwieldy list of different sciences: he had stumbled into the conception of a new science.

Indeed, decisive for this new development was a new, forward-looking understanding of science: the Humboldtian science, founded through his voyages and established with his subsequent writings. Alexander von Humboldt was not only the founder of individual disciplines such as phytogeography or Native American Studies but also, sensu Michel Foucault, a founder of discourse, the inventor of a new understanding and a new 
scientific practice which defied the increasingly popular nineteenth-century trend of separating nature from culture. His equally comprehensive and complex concept of life understood both nature and culture as an inseparable living entity.

For his journey into the New World marked the dawn of a profound nexus of thought amongst all those disciplines in which Humboldt had previously familiarized himself and deepened his knowledge. His concept of science remained deeply nomadic and by no means monadic. His brother Wilhelm had already recognized early on that his younger sibling's great gift lay in creative combination: the ability to join by dint of thought what at first glance does not belong together. ${ }^{5}$ It was the beginning of a transdisciplinary science whose relevance even today defies obsolescence. On the contrary: our times of ecological catastrophes call for a way of thinking that opens up our planet Earth in all its relations and interactivity and which ensures that the various influences of the world's cultures on nature are no longer culpably neglected.

The immense, albeit temporary success of Daniel Kehlmann's bestseller Die Vermessung der Welt has branded the Prussian as a mere world surveyor. Alexander von Humboldt was certainly a man of numbers, constantly taking measurements, running different measurement series day and night. Yet he never let his measurements lie untouched; they always led into more general observations inspired by his spirit of creative combination. For him, it was always about the big picture.

Numbers undoubtedly testify to his profound shift toward empiricism and the empirical basis implicit in the conception of his science. Thus we find in his writings a myriad of lists and enumerations with different measurements in both the natural and cultural sciences alike. But the numbers sometimes took on the same significance that Dante-whom he admiredascribed to them in the universe of his Divine Comedy, that is, in his cosmos. While such numerical symbolism did not obscure the precision of his data, it always aimed at the universal. Recent research from a Toulousain research group led by Pierre Moret came to the hardly surprising conclusion that his Tableau physique des Andes (1807) - to which we will have to return in detail-ought not to be taken too literally and empirically, as his entries were certainly not derived solely from Chimborazo, but rather encompass the entirety of today's Ecuadorian high Andes (see Moret et al. 2019). They offered a fractal model as opposed to a precise list of the locations of certain plants at a particular volcano, for Chimborazo served more than anything as a symbolic mountain for him: he had never reached its 
summit. Here, rather than yielding to failure, Humboldt emphasized that science is a pursuit without telos, that there is always a way forward and beyond, as he also indicated in his Naturgemälde.

Alexander von Humboldt was a precise observer of people, and not least of the indigenous population in the Americas. He quickly overcame his initial prejudices whose roots derived from the relevant writings of the philosophes of the eighteenth century; indeed, he became increasingly absorbed in American cultures and would ultimately come to be known as the founder of Native American Studies, the study of the diverse cultures across the Americas. Here, too, he surveyed everything he came across. But his primary interest lay not in measurements and numbers, not in measuring and calculating, for he developed a profound understanding of the cultural developments that the various American peoples had lived through and sought to juxtapose them with Western antiquity and with cultures worldwide. Drawing on Clavijero's work and many other studies, he developed a historically sound picture of the indigenous American civilizations. Furthermore, as his later writings such as Vues des Cordilleves et Monumens des Peuples Indigènes de l'Amérique indicate, he began to study complex relationships between the world's most diverse cultures ${ }^{6}$ integrating them into a grand overview of human cultures.

The younger of the Humboldt brothers hardly limited himself to the study of natural phenomena. To label him as a mere natural scientist is indeed as traditional as it is false. Such a view has been known to flow about in Germany and occasionally in other European countries, but never in Latin America; for there his intensive engagement with, for instance, American history and culture is well known. For Humboldt, nature and culture were intimately intertwined. This process of insight into the indissoluble relationship between culture and nature is documented in his Amerikanische Reisetagebücher in a very precise and yet quotidian manner. This resulted in far-reaching scientific consequences.

To be sure, it is not entirely clear how the central axiom of the nascent Humboldtian science made its way into his travel reports. Situated in the midst of a disparately formatted passage scribed in French, it almost literally glowed in German: "Alles ist Wechselwirkung" (Everything is reciprocity). ${ }^{7}$ The axiom emerges like an epiphany. Very suddenly the all-encompassing fundamental formula was found: the basic formula of the scientific practice that Humboldt had long since developed on his journey through the American tropics-the Humboldtian science. The location and surroundings seem to indicate a spontaneous moment of 
enlightenment, something Humboldt had certainly long since contemplated and derived but had never expressed with such simplicity. But thereafter he saw even more clearly how intimately everything was connected via reciprocity and, above all else, interactions.

It is fascinating to peek over Humboldt's shoulder amidst this cognitive process in his Amerikanische Reisetagebücher. Indeed, his daily field research is currently being transformed into a series of transdisciplinary investigations: beyond the network of rivers ranging from the Orinoco to the Amazon and the network of volcanoes in the high Andes of presentday Ecuador, the interconnectivity between the indigenous languages and the interrelationships among the different cultures of America are also becoming increasingly visible. Lists appear everywhere: lists of languages, lists of volcanoes, lists of rivers.

And what is more: Humboldt recognized on multiple occasions and with great clarity the extent to which humans with, for example, agriculture encroach on seemingly inexhaustible natural resources and, through deforestation for shipbuilding or access to more cultivable land, devastate the water balance. Historical sources had already alerted him to the destructive effects of human culture. He develops this into a recognition of ecosystems, yet all of this is coupled with an assessment of the respective culture of the corresponding population groups. The matter of biodiversity is not a purely bioscientific issue, but rather one that essentially involves cultural aspects.

Indeed, it is cultural backgrounds that determine people's actions, as he illustrated by singling out the destruction of the lake area in the heart of Anáhuac in present-day Mexico:

The Spaniards treated the water as an enemy. Apparently, they want this New Spain to be as dry as the inner districts of their Old Spain. They want nature to resemble their morals, and they are not doing a bad job of it. [...] They have not managed to reconcile the two objectives: the security of Mexico City and the irrigation of the land. The lack of water makes the valley infertile, unhealthy, the salt level increases, the dryness of the air increases. ${ }^{8}$

Humans intervene in nature according to culturally shaped ideas and, in Humboldt's words, harbor the desire for nature to resemble the respective group's morality as well as its origin. These are insights into the interwovenness of culture and its destruction of nature which, until recently, had 
hardly been used in research and thus remain largely unaddressed. There exists a plethora of natural science institutions bearing the name Humboldt, yet a shortage of such institutions which represent equally both the natural sciences as well as cultural studies.

The realization that Alles ist Wechselwirkung brings together geology and volcanology with the mythology and the symbolism of the indigenous populations, infusing into what Humboldt perceived in the American tropics as the grand majesty of nature an awareness of scientific knowledge still to be pursued while, in turn, also alluding to the fragility of all human knowledge. For not only is everything connected with everything: everything interacts (interagiert) with everything. Here it is also worth noting to what extent Humboldt increasingly resorts to the knowledge of the indigenous peoples, often relying on repeated reminders from his Indian guides for the names of animal noises amidst the darkness of the jungle and also admiring their ability to find their way around in utter darkness.

Returning from Chimborazo and searching out in pitch-darkness the proper path down, Humboldt again revealed his almost compulsive affinity for numbers, this time not without a stroke of self-directed irony:

We moved first on foot, then on horseback. We amused ourselves by counting how many times each one of us fell whilst walking. In less than three hours, Don Vicente Aguirre, who strode behind me, counted 123 falls for me, and I counted 34 for the Indian walking ahead of me. It thus follows that the skill of an Indian compared to a white man is 34 to $123 .{ }^{9}$

Nothing was beyond the scope of Humboldt's interests. He recorded everything in his Amerikanische Reisetagebücher, annotated extensively and wondered all the meanwhile how his recordings and insights might be related - that is, almost everything. Indeed, Humboldt's reticence is also of significance: reticence which speaks volumes, but which can only briefly be addressed at present.

It is thus hardly imaginable that the Prussian researcher, whose scope of interest nothing eluded, would have abstained from experimentation with the indigenous hallucinogens whose presence in certain regions of the high Andes had been well known for centuries. Yet his travel reports contain no mention of such. Humboldt was well aware of the fact that his Amerikanische Reisetagebücher would one day be publicly accessible and, accordingly, remained silent, concealing his more intimate emotions: such was not intended for public scrutiny. 
But the knowledge and insight of the Native Americans proved at once interesting, intriguing, and fascinating to Humboldt. Exemplary of his interest is a passage from Report VII, which highlights both the boundaries of his own knowledge as well as his own senses.

When we botanized, we consulted Indians to find out the names of trees. Here one encounters trunks that tower so high that one cannot distinguish the foliage. The Indian takes the bark in his mouth, chews on it and then says with the utmost certainty that it is such or such tree. I, in turn, chewed on the bark, and could not detect any difference in taste among 15 trees. They all seemed to me to be equally tasteless. ${ }^{10}$

The tedious learning process reflected in his Amerikanische Reisetagebücher would ultimately encompass all branches of science and knowledge. Humboldt proved willing to reexamine all areas of his knowledge against reality and empiricism and to correct manifest errors. And where his mistakes proved salient, he grew more sapient. Thus, during his American journey, the Prussian travel writer evolved from a staunch Neptunist who, like Goethe or his mentor Werner, believed in the rock-forming power of aquatic sedimentation, into a budding Plutonist, who saw volcanic phenomena as holding a far greater influence on the formation of rocks. Yet throughout his life, he enjoyed a warm friendship with Goethe and Werner: even if Goethe resented him, Humboldt was a diplomatist, and a skilled one at that.

The roughly 4000 manuscript pages containing some 450 sketches and drawings (see Ette and Maier 2018) constitute a detailed image of a tropical world in which Humboldt quickly felt both happy and homely. But it was not only in various climates where he felt at home: Humboldt wrote in a great range of languages, convinced that the world's complexity could not be adequately expressed when restricted to the viewpoint of one single language. If a report began in German, he was wont to transition into French as the journey progressed, neglecting neither Latin nor Spanish and often including references to other (and especially indigenous) languages. Humboldt was truly multilingual both in tongue and thought.

Allow me here to briefly touch on the materiality of his writing: $\mathrm{He}$ mixed his inks himself which, beyond allowing for the very precise dating of certain passages from his Amerikanische Reisetagebücher (see Thiele 2016; Bispinck-Roßbachere 2016), after the cap-sizing of his pirogue also prevented their utter destruction owing to the ink's water resistant 
properties. Decades later, Humboldt circled in pencil the water stains still preserved in the paper, noting affectionately, "Water from the Orinoco." More importantly, however, his writing and penmanship - continually rising upward and toward to top right as characteristic of him-were preserved and thus maintain all the processes of knowledge which have been passed down to us with such impressive clarity. These manuscript pages feature a myriad of lists and tables of every sort, something which we shall return to shortly. Humboldt delighted in creating lists of things that he was investigating, that he loved, that he was measuring, or that he simply wished to remember.

Let us now attempt to gain a broader perspective. Accompanying the Humboldtian science was also the development of a Humboldtian approach to writing. In his travel manuscripts, the philosopher and natural scientist from Berlin wrote neither in diary-like fashion - that is, day after day-nor in a manner typically associated with travelogues - that is, following a given travel route; he arranged his materials neither by discipline nor thematically. In other words, there exists no consistent, continuous logic in his writing, which was without a doubt not only multilingual, but also multilogical. What, then, did his writing consist in?

Lists are first and foremost linear, albeit discontinuous discourse elements. Alexander von Humboldt did not write continuously, but rather discontinuously: He often left large free spaces between his entries and later filled in these gaps successively. In doing so, he practiced an island approach to writing or, more precisely, an approach featuring small textislands which were not recorded in a continuous sequence, but rather linked relationally with one another. Each text-island, only occasionally titled, served as a small work in itself with its own logic and voice-yet at the same time an island world insofar as each island was situated in a multirelational network with other islands.

This enabled a much more precise implementation of the foundational principles of his scientific concept, in which everything was necessarily interwoven with everything and, moreover, interacted reciprocally with everything. Thus, in his Amerikanische Reisetagebücher, Alexander von Humboldt found his characteristic style, which he later tinkered with in his printed works in various ways. He thereby succeeded in implementing discontinuity as a fruitful underlying principle in his writing. This ought to prove of great importance, especially where lists are of interest.

But Humboldt was also a deeply political mind. He spoke out vehemently against all forms of slavery and servitude. His travel manuscripts 
included oftentimes shocking scenes of a colonial ruler exercising violence, depictions which must have literally branded themselves into his readers' memory. His criticism of colonialism, which ultimately neutralized any hopes of accessing the British Empire on the Asian continent, became harsh and biting, particularly in the second half of his travel manuscriptsa fact supported by his remarks in Report IX about the native miners in Mexico:

Apart from their pants, they walk completely naked, sweating terribly, are usually leaning on a small stick, barely 10 inches long, and are stretched out on stairs as if walking on all fours. Unhappy offspring of a race robbed of its property. What precedent exists of a whole entire nation losing all its property? A strong Tenatero remains burdened with $12-14$ arrobas of stone for 6 hours and walks up and down the 32000 steps in 1 shift! What contrast, people talk daily about the energy of the white race and weakness of the Indians. The latter make 8 - 10 journeys loaded, and we, we crawl, if we are unburdened and well-fed, only once out of the shelters of Valenciana daily. I have found myself quite miserable. ${ }^{11}$

Alexander von Humboldt continued entering additions, deletions, amendments, and updates in his Amerikanische Reisetagebücher with great precision and equal affection until his final days. This chronicle of his life is a treasure which alters the perception of that Prussian cultural and natural scientist and which shows us a humane and almost present Humboldtwith all his contradictions, all his vehemence, all his science, and all his truth. Consequently, any attempt to construct a monolithic image of a Humboldt compiling his lists, constellations, and tables according to a single logic, perhaps as a mere "surveyor of the world," can only be described as misguided. Never in his long life of research spanning more than seven decades was he afraid of contradictions.

\section{Contradictions and Weaving Flaws}

Attentive reading often reveals the tensions, and sometimes contradictions, between many of Humboldt's statements. It seems obvious that Humboldt deliberately built weaving flaws (Webfehler) into many other constellations and lists. The following shall elucidate some of the characteristic contradictions in Humboldt's work by way of example. Even in the "Introduction" to his Reise in die Äquinoktial-Gegenden des Neuen 
Kontinents (dated "Paris, February, 1812"), ${ }^{12}$ which appeared in print for more than a decade and a half, Alexander von Humboldt had drawn a clear line of demarcation between the hemispheres, between the "Old" and the "New" World, not least by including the typical objects expected by the contemporary public in travel reports:

I am more than aware of how a traveler in America is at a disadvantage with respect to those who describe Greece, Egypt, the banks of the Euphrates or the South Sea Islands. In the Old World it is the civilized peoples and the gradations of their civilization that lend the picture its principal character; in the new world, however, the individual vanishes, as it were, together with his problems amidst a wild and imposing nature. The human race offers here only a few relics of indigenous, culturally underdeveloped hordes or the uniformity of customs and institutions that have been planted by European colonists on these distant shores. ${ }^{13}$

The stark contrast between a world of culture and a world of nature opened up, as it were, a travel moment which the reading public would follow for nearly two decades until the publication of the third and final volume in April 1831 — and thus until the abrupt end of the actual travel report. Not long thereafter, in 1813, and again in Paris, Humboldt drafted his "Introduction" to Ansichten der Kordilleren and-despite numerous contradictions-would designate Ancient Greece as the locus of the world's cultures. Particularly in his Vues des Cordillères et Monumens des Peuples Indigènes de l'Amérique, Humboldt hands his readers a great deal of evidence for the diversity of the "monuments of the native peoples of America," which the Prussian scholar had scrupulously examined on his voyage through the most diverse regions of the Americas as well as in the libraries and archives of both the Old and New Worlds. Indeed, as his Amerikanische Reisetagebücher demonstrate, he had already learned much from the complexity of American cultures and would later become one of the founders of Native American Studies. Why, then, did he retain his bias toward Western antiquity_-something which both his brother Wilhelm and the entire Western educational system would undoubtedly approve of - when, at the same time, he had developed a much broader, panoramic view of world cultures in his writings?

The contradictions in his œuvre would remain and even intensify. What might have prompted Humboldt to take two essentially disparate views on two distinct introductions to volumes written within a year of one another, 
each depicting important parts of his American travel work? Whereas in his travel report he resorted to the bromide of the American continent as the "realm of Nature" 14 which, apart from Europeans and Creoles, was populated by only "a few relics of indigenous, culturally underdeveloped hordes," in his Ansichten der Kordilleren he vehemently denounced the widely held prejudice that America was a continent bereft of culture and history prior to its "discovery":

A people whose festivals were arranged according to the stars and whose calendar was engraved in a public monument probably had a higher level of civilization than it is granted by those sharp historians who have taken aim at America. These authors regarded as barbaric any such human condition far removed from a type of culture formed in accordance with certain systemic ideas they held. These rigid distinctions between barbarism and civilization are unacceptable. ${ }^{15}$

The alleged contrast between civilization and barbarism is in fact a constant source of controversy for Humboldt, something which we shall consider at a later point. Nevertheless, the contradictions between the two passages are striking, almost certainly owing to the fact that in the introduction of his travel report Alexander von Humboldt employed a popular cliché only to paint a much subtler portrait of the continent and its cultures at a later point in his Relation historique. Playing around with clichés and with the banal was by no means an uncommon Humboldtian practice: he loved to play with the expectations of his readers only to disappoint them in unexpected ways. Thus, the rigid dichotomy observed in the travel report between the two worlds in Humboldt's thought remains open to impugnment, especially since a "weaving flaw"-often a hallmark of his systematizing enumerations-managed to creep into the aforementioned account.

The supposedly clear division in the listings of world regions was ever so subtly fragmented by the addition of the hardly old-world South Sea Islands, which had been made famous by the travel reports of some LouisAntoine de Bougainville, Georg Forster, or James Cook. It was with the aid of the small, apparently illogical deviations - the supposedly minor weaving flaws - that Humboldt succeeded in stripping his ideas of the dogmatic schematism which he decried as the "systematic ideas"16 of Raynal, de Pauw, or Robertson. No, he did not seek systematic ideas. 
Rather, he sought an empirical, material, and experimental basis for his vision without, of course, neglecting a theoretical view of the whole.

Both in the Vues des Cordilleres as well as in the Relation historique, Humboldt proves himself fully capable of presenting the Old and New World as no longer fixed in opposition, but rather as complementary and mutually interactive. In the place of the absolute alterity that had prevailed in the so-called Berlin Debate on the New World, (see Bernaschina et al. 2015) he placed a kind of mutual interdependence which could underlie his basic formula Alles ist Wechselwirkung. Incidentally and unlike any of his contemporaries, he was practiced in citing cultural evidence for just such cases which, beyond the ephemeral traces of hunting populations and other nomadic tribes, rather impressively proved the presence of thriving indigenous cultures. For him, the division between civilization and barbarism constructed by dint of European pride was a chimera, both a foreignand self-delusion.

Comparable contradictions in Humboldt's writing are also seen at other levels. What Humboldt in the first volume of his travel report denounced as "uniformity" and later in the third volume-in light of the sweeping dissemination of Spanish-heralded as an enduring "monument to national glory," 17 was depicted in other writings as an important element in facilitating communication across national borders, which would soon benefit the future development of the Spanish-speaking world. $\mathrm{He}$ had already noted in his Amerikanische Reisetagebücher that of all the European languages, Spanish was "spoken by the largest number of people outside Europe." 18 Not even Arabic or Chinese had "spread over such a vast area from Nueva Galicia and California to Cape Horn, the Philippines and the Maluku Islands," and if one were to add Portuguese, which was closer to Castilian than Catalan or Valencian, then one could "include the whole of eastern India, Persia and the Asian archipelagoes, where Portuguese served as the language of commerce and business." 19 Although from a modern linguistic perspective the inclusion of lusophones amongst hispanophones is hardly permissible, Humboldt's reflections on Spanish as a world language are more pertinent today than ever.

The prevalence of Spanish was rivaled only by English, which in turn had spread over "the majority of North America and the West Indies, Bengal and Orissa, the coast of Madras." ${ }^{20}$ But with altered political conditions, it was Spanish whose potential for development held the greatest promise: 
If the Spanish nation one day obtains political freedom and intellectual education, this dissemination of the nation's language will afford a great advantage primarily to Europeans. This will be particularly manifest in South America. That which is printed in Mexico can be read in Caracas, Lima, Buenos Aires and Manila. Such ease in the spread of ideas and sensibilities! ${ }^{21}$

In this journal entry-penciled on his way to Bogotá on the Río Magdalena-Alexander von Humboldt conjured up the worldwide dissemination of those European languages on the New Continent, this "mapping" of a language atlas amplifying the contrast between North and South America-and thus between the "two Americas"-while at the same time transcending these hemispheric borders considerably. It was characteristic of Humboldt's manner of thinking and writing that even his listings of South American regions or capitals contained many inconsistencies, running contrary to any unifying logic. On the one hand, Mexico by no means belongs to the South American subcontinent-not even according to Humboldtian classification - and on the other hand, Manila- similar to the South Sea Islands in the list of places in the "Old World" discussed earlier-points beyond both South America and the entire American continent. Simple authorial lapses? Unlikely. So here, too, we come across more weaving flaws in a typical Humboldtian list of places and regions.

The frequent inconsistencies in Humboldt's lists and sequences may at first glance appear as mere slips. The frequency of his "oversights" should certainly make us sensitive to the fact that Humboldt, transcending fixed systematic ideas, was clearly concerned with the ever-changing perspectives of what prima facie appeared like simple demarcation lines. The lists of pictorial representations in his Vues des Cordillères also contain similar weaving flaws, the illusion of coherency a sleight of hand. Such weaving flaws always give rise to gaps in a list's consistency, and through such gaps different arrangement patterns and logics become tangible. And indeed, the individual parts of the Vues des Cordillères elude any consistent logic and arrangement.

We are thus initially astonished to discover that Humboldt's only systematic practices consist in traversing and undermining boundaries and divisions: fresh relationships and connections constantly pop up, terminology and perspectives appear in constant flux, and the inclusion of other phenomena always gives rise to new contexts which had previously been 
buried. And so arose a multi-perspectivity along with the flexible, modular divisions it affords which, owing to constant shifts and overlap between different spaces, bring into focus not the borders and the territories connected with them, but rather the relationships between individual areas and the possibilities for communication and exchange associated with them. Humboldt always offers his readers different ways of approaching the logic of a given phenomenon.

In this way, the internal relationality at the hemispheric level can be worked out in its complexity while still applying to the American hemisphere an external relationality which transcends the American frontiers, as Humboldt demonstrated with the example of languages as a means of communication par excellence. ${ }^{22}$ Let us note, then, that Humboldt incorporated weaving flaws into many of his lists in order to undermine categorical classifications and to highlight transareal relationships. Behind the apparent order of a list lurks a force which pushes such order to its limits, giving way to other forms of logic.

\section{The Tableau Phrsique Des Andes}

It is not possible in this limited context to exhaustively work through the hundreds, even thousands of lists riddled throughout Alexander von Humboldt's œuvre. The lists are too diverse to be presented critically in a single, brief overview. As such, beyond what has already been said, we can only attempt to present our considerations in a representative manner. Exemplary of this is the outstanding visualization of the Humboldtian science which, in a unique fashion, presents this concept of science in all its complexity while also capturing its integrative approach in a total view ("Totaleindruck").

So let us turn our attention to his spectacular Tableau physique des Andes et Pays voisins, well established as one of the most famous scientific representations of the entire nineteenth century. It goes back to a Humboldtian draft from 1802 in Guayaquil, Ecuador, which appeared in 1807 in a separate volume from his Géographie des Plantes, his first scientific book publication following his travels and also the foundation of phytogeography. Although it represents the state of his science around 1807 and was associated with that half-century of scientific activity, it is of fundamental importance for the entire Opus Americanum.

Relying both on ideas from pasigraphy as a formula language to immediately grasp complex relationships and on reflections concerning the total 
view or "Totaleindruck" from his brother Wilhelm von Humboldt, ${ }^{23}$ Alexander von Humboldt's Tableau physique asserts a unity of nature and art. This is suggested not least by its German title, Naturgemälde der Tropen, which characterizes the work as the "painting" of nature. In this unique combination of science and aesthetics (aesthetics is here not to be understood as "ornamental" or "decorative," but rather as the true, artistically constructed nexus of knowledge between all areas of knowledge and science) the Prussian natural and cultural scientist was able to work out those elements of his voyage which best represented his manner of thinking, writing, and science. An emblem of the Humboldtian concept of science, the Tableau physique remains without a doubt unsurpassed by any of his other imaginings.

To begin, it ought to be emphasized that in that island-like stretch through the Andean volcanoes of Chimborazo and Cotopaxi, literally everything is in motion. Firstly, the continental shelf is moving: Humboldt had already noticed earlier how the contours of South America neatly fit into those of Africa, a fact which suggested a westward movement of the South American continent. Secondly, the entire geography, as represented in the tableau, is moving: the smoking maw of the volcano indicates that the rock which composes the volcanic cones is in constant "plutonic" motion. Thirdly, and most importantly, it is the plants that are on the move; and indeed, the phytogeography founded by Humboldt is not a mapping or static inventory of plant locations, but rather an investigation of the migration of plants on the surface of (and of the cryptogams below) the earth. Lastly, the various parameters such as the snow line and the various altitude levels are also in flux, the borders of both flattening out near the poles, as the Tableau physique notes.

It is not only nature and art that stand in such close relation in this particular Naturgemälde but also, and perhaps most importantly, text and image. This applies equally to both the painting itself as well as to the tables listed scientifically on either side of it, where Humboldt recorded his remarks and all measuring data imaginable. On the left hand side there appear heights listed in meters, followed by a list of height measurements of various great mountains across the globe, which at that time were known and verifiably measurable, from the peak of Chimborazo-in 1807 still considered to be the highest mountain in the world - all the way to Kinekulle in Sweden; then comes a list of electrical or weather phenomena at high altitudes followed by soil cultures as a function of altitude. 
Within the previous list there is a bracketed addition from Humboldt reading: "Esclaves Africains introduits par les peuples civilisés de l'Europe." Here he clearly makes reference to the barbarism of civilization as well as to the civilization of barbarism exhibited in slavery and the slave trade, for which Europeans were responsible. The mention of African slaves also supports the presentation of a movement encompassing the entire range of nature and culture, for it was the devastating biopolitics of Europe with its enslavement and deportations that changed the population structure of the American colonial territories so fundamentally.

This addition anchors the Naturgemälde der Tropen-Länder without question within an ethical-political space of decisive importance for the Prussian researcher. At this point we are, of course, able to recognize one of Alexander von Humboldt's many weaving flaws and, at the same time, one of the lists which enabled him to evade pure schematics and which, naturally, incorporated the political into his scientific investigations. Indeed, this entry was doubtlessly a ruse which allowed him to allude to the burden of a colonial and colonialist past which, at that time, still persisted in the form of slavery.

Here is a cursory glance at the remaining tables or lists on the left-hand side: on the weakening of gravitation, on the blueness of the sky as determined with the aid of a cyanometer, on the decrease of humidity, and on air pressure measurements. Enough for now on the first ten listings on the left-hand side, which one could certainly examine in more detail.

The framing of the Naturgemälde featuring height scales in both toise and meters is carried onto the right-hand side and includes air temperature readings at various altitudes, measurements on the chemical composition of air, on the lower limit of perennial snow, information on animals located at various altitudes as well as on others such as crocodiles which do not inhabit that region. At this point, Humboldt sowed tiny seeds of potential narratives which he here only hints at, but which never develop into a full narrative. This is followed by information on the boiling point of water at different altitudes and on the respective geological conditions primarily of the Andes and the surrounding regions, but also with a view to relationships across the globe; here Humboldt also expressed some theories on the nature of the lowlands, plateaus, and peaks. And finally, there appears information on light intensity as a function of altitude as well as another scale with altitudes in toise.

These diverse listings possess something at once fascinating and disconcerting. On the one hand, they condense all those measurements which he 
had carried out during his journey through the American tropics in impressive fashion; on the other hand, they single out objects and phenomena which leave one wondering what sort of logic guided him and why he selected precisely these details instead of others. Indeed, he could have opted for completely different objects in his measurements; furthermore, it is easy to imagine a range of topics which Humboldt disregarded in his Tableau physique - lists on the highest established human settlements, on the location of important cities and capitals in relation to their altitude, or on the infrastructure of the Andean areas, to name but a few examples. There is no doubt that the lists obey a scientific logic within Humboldt's science but, at the same time, they possess a nature reminiscent of Jorge Luis Borges' list, which occasioned the epistemologist Foucault's laughter and prompted him to write Les mots and les choses. Yet it remains unclear which logic was at play as the Prussian selected his lists and equally unclear why some lists bear traits of narrative expressed to varying degrees.

The tables and listings which Alexander von Humboldt shows in his Naturgemälde correspond not only to the state of scientific knowledge he had arrived at in 1807 . For more than fifty years-more than half a century still-he would continue to work on these observations, especially with regard to the American continent, and to expand his ideas considerably with respect to his illustration of phytogeography. From this point of view, it seems almost essential that Humboldt would have employed here an epistemology of expansion and enlargement- that his lists could have been printed as they were, but also in an utterly disparate manner while still retaining those weaving flaws which render them so readable and insightful for us today. Transdisciplinary to the core, his lists lead us down paths which traverse the Humboldtian science from all directions.

Researchers have tended to overlook the detailed title of his entire Naturgemälde der Tropenländer. The full title of the original French version reads: Géographie des plantes équinoxiales. Tableau physique des Andes et Pays voisins. Dressé d'après des Observations \& des Mesures prises sur les Lieux depuis le $10^{\circ}$ de latitude boréale jusqu'an $10^{\circ}$ de latitude australe en 1799, 1800, 1801, 1802 et 1803. Par Alexandre de Humboldt et Aimé Bonpland. Esquissé et rédigé par M. de Humboldt, dessiné par Schönberger et Turpin à Paris en 1805, gravé par Bouquet, la lettre par Beaublé, imprimé par Langlois.

Its designation as Tableau physique $e^{24}$ (like the German Naturgemälde) clearly demonstrates the mutual interrelation and influence of nature and 
culture (or art). Moreover, the title hints at the intimate collaboration between scientists and artists in the configuration of this particular cut through the Andes. The detailed title configures a group of authors of this Tableau physique. At the same time, the title gives sufficient indication of the breadth of collected measurements, which refer not only to Chimborazo, but to a large spatial-temporal expanse spanning his entire journey and, as such, represent a model which must be understood as a fractal of the entire South American subcontinent. The notes provided by the aforementioned French research team, which indicated that the data on plant height could not be verified on Chimborazo, appears to have already been anticipated in its title. To doubt the precision of the data and measurements in the Tableau physique would border on gross negligence, bearing in mind the exemplary character of Humboldt's visualization.

The textual entries in the Naturgemälde der Tropenländer themselves appear in three different forms. First, there are details about the journey itself such as the furthest point reached by Aimé Bonpland, Carlos Montúfar, and Humboldt on Chimborazo-yet another indication from the Prussian that they did not reach the summit. Second, the Tablean contains information on the altitudes which other expeditions in the Andes (such as those of Bouguet and La Condamine) or the Alps (such as those of Saussure) had reached, while also recording the world record for the highest altitude achieved during the ascent of a French hot air balloon shortly thereafter. Lastly, information is provided which is not merely comparative, but also relational in nature. This includes not only references to mountains that Humboldt climbed in other areas (such as Popocatépetl), but also elevations on a global scale, as his reference to Vesuvius demonstrates. Rather than drawing comparisons, these entries engender relations and thereby express Humboldt's fundamental and transareal understanding of the globe.

The lists of Alexander von Humboldt are thus truly wonders unto themselves. They serve the Prussian researcher's discontinuous writing style and, in many respects, can be described not only as multilingual, as are his writings, but also multilogical. They contain narrative cores, some of which Humboldt developed elsewhere, or introduce fundamentally different themes such as slavery and the barbarism of "civilized" Europeans, thereby introducing a fundamental ethical dimension to the aesthetics of the Tableau physique. They represent forms of writing that Humboldt employed in his travel manuscripts, but also in his printed scientific 
treatises as a means of naming factors involved in the fundamental process of mutual interactivity.

Last but not least, the lists and enumerations throughout Humboldt's œuvre evince their own imaginative nature, evidence that their author created them to convert the burdens of the past or present into a delight that could shape and enrich both knowledge and science. They are lists of an epistemology of constant expansion and thus allow us to occasionally make out the gentle laughter of the list-making author.

\section{Notes}

1. For more on this topic and on the complex, asymmetrical relations to Latin American literature, see Ette (1994).

2. For a scientific overview of the various aspects of Humboldt's work, see Ette (2018).

3. See the "Preface to the second and third edition" (dated March, 1849) of his Ansichten der Natur, mit wissenschaftlichen Erläuterungen, 9.

4. See Humboldt, Alexander von, Die Jugendbriefe 1787-1799, 74.

5. See Humboldt, Wilhelm von, Briefe an Karl Gustav von Brinkmann, 60.

6. See the German edition from Humboldt, Alexander von: Ansichten der Kordilleren und Monumente der eingeborenen Völker Amerikas, (2004).

7. Humboldt, Alexander von, Reise auf dem Rio Magdalena, durch die Anden und Mexico, vol. I: Texte, 358.

8. All quotations from Humboldt are original translations by Nathan Anderson, who rendered this article into English. In this instance, see Humboldt, Alexander von: Reise auf dem Magdalena, durch die Anden und Mexiko, vol. 2, 254.

9. See Humboldt, Alexander von, Das Buch der Begegnungen, 236.

10. See Humboldt, Alexander von, Das Buch der Begegnungen, 270.

11. See Humboldt, Alexander von, Das Buch der Begegnungen, 315.

12. See Humboldt, Alexander von, Reise in die Äquinoktial-Gegenden des Neuen Kontinents vol. I, 40.

13. See Humboldt, Alexander von, Reise in die Äquinoktial-Gegenden des Neuen Kontinents, vol. I, 35-36.

14. See Humboldt, Alexander von, Reise in die Äquinoktial-Gegenden des Neuen Kontinents, vol. I, 35-36.

15. See Humboldt, Alexander von, Vues des Cordillères, 194.

16. See Humboldt, Alexander von, Vues des Cordillères, 194.

17. See Bernaschina, Kraft and Kraume (2015), vol. II, 1462.

18. See Humboldt, Alexander von, Reise auf dem Rio Magdalena, durch die Anden und Mexico, vol. I, 75. 
19. See Humboldt, Alexander von, Reise auf dem Río Magdalena, durch die Anden und Mexico, vol. I, 75.

20. See Humboldt, Alexander von, Reise auf dem Rio Magdalena, durch die Anden und Mexico, vol. I, 75.

21. See Humboldt, Alexander von, Reise auf dem Rio Magdalena, durch die Anden und Mexico, vol. I, 75.

22. Regarding the spatial-geographical, temporal, social, literary, genrespecific, intermedial, and cultural dimensions of this new American discourse, see Ette (2004).

23. See Trabant (1986); Hard (1970); Schneider (2016).

24. See the important work on this aspect of Humboldt's science by Kraft (2014); it is this work which provided me with the note on African slavery in Tableau physique.

\section{REFERENCES}

Bernaschina, Vicente, Tobias Kraft, and Anne Kraume, eds. 2015. Globalisierung in Zeiten der Aufklärung: Texte und Kontexte zur „Berliner Debatte“ um die Neue Welt (17./18. Jh.). 2 vols. Frankfurt/Main: Peter Lang Edition.

Bispinck-Roßbachere, Julia. 2016. Ein Blick in die Tiefe - Kodikologische und materialtechnologische Untersuchungen an den Manuskripten Alexander von Humboldts. In Horizonte der Humboldt-Forschung: Natur, Kultur, Schreiben, ed. Ottmar Ette and Julian Drews, 193-205. Hildesheim/Zürich/New York: Georg Olms Verlag.

Descombes, Vincent. 1981. Das Selbe und das Andere: Fünfundvierzig Jahre Philosophie in Frankreich 1933. 1978. Trans. Ulrich Raulff. Frankfurt/ Main: Suhrkamp.

Eco, Umberto. 2009. Die unendliche Liste. Trans. Barbara Kleiner. Munich: Carl Hanser Verlag.

Ette, Ottmar. 1994. Asymmetrie der Beziehungen: Zehn Thesen zum Dialog der Literaturen Lateinamerikas und Europas. In Lateinamerika denken: Kulturtheoretische Grenzgänge zwischen Moderne und Postmoderne, ed. Birgit Scharlau, 297-326. Tübingen: Gunter Narr Verlag.

- 2004. Die Ordnung der Weltkulturen: Alexander von Humboldts Ansichten der Kultur. HiN - Alexander von Humboldt im Netz. Internationale Zeitschrift für Humboldt-Studien 5 (9): 8-29. https://www.hin-online.de/ index.php/hin/article/view/50. Accessed 7 Jan 2021.

. 2016. Weiter denken: Viellogisches denken/viellogisches Denken und die Wege zu einer Epistemologie der Erweiterung. Romanistische Zeitschrift für Literaturgeschichte/Cahiers d'Histoire des Littératures Romanes (Heidelberg) XL (1-4): 331-355. 
, ed. 2018. Alexander von Humboldt Handbuch. Leben - Werk - Wirkung. Mit 52 Abbildungen. Stuttgart: J.B. Metzler Verlag - Springer Nature.

Ette, Ottmar, and Julia Maier. 2018. Alexander von Humboldt: Bilder-Welten. Die Zeichnungen aus den Amerikanischen Reisetagebüchern. Munich/London/ New York, Prestel.

Foucault, Michel. 1970. The Order of Things: An Archaeology of the Human Sciences. New York: Vintage.

Hard, Gerhard. 1970. „Der Totaleindruck der Landschaft“: Re-Interpretation einer Textstelle bei Alexander von Humboldt. In Alexander von Humboldt: Eigene und neue Wertungen der Reisen. Arbeit und Gedankenwelt, ed. Herbert Wilhelmy, Gerhard Engelmann, and Gerhard Hard, 49-73. Wiesbaden: Steiner.

Kehlmann, Daniel. 2005. Die Vermessung der Welt. Reinbek: Rowohlt.

Kraft, Tobias. 2014. Figuren des Wissens bei Alexander von Humboldt: Essai, Tableau und Atlas im amerikanischen Reisewerk. Berlin/Boston: de Gruyter.

Moret, Pierre, et al. 2019. Humboldt's Tableau Physique Revisited. PNAS 116 (26): 12889-12894. https://doi.org/10.1073/pnas.1904585116.

Schneider, Birgit. 2016. Der „Totaleindruck einer Gegend“: Alexander von Humboldts synoptische Visualisierung des Klimas. In Horizonte der HumboldtForschung, ed. Ottmar Ette and Julian Drews, 53-78. Hildesheim/Zürich/ New York: Georg Olms Verlag.

Thiele, Matthias. 2016. „Im Angesicht der Dinge“: Ambulatorische Aufzeichnungspraktiken und Schreibtechniken des Notierens bei Alexander von Humboldt mit Seitenblicken auf Georg Forster, Thomas Jefferson und Adelbert von Chamisso. In Horizonte der Humboldt-Forschung: Natur, Kultur, Schreiben, ed. Ottmar Ette and Julian Drews, 319-348. Hildesheim/Zürich/ New York: Georg Olms Verlag.

Trabant, Jürgen. 1986. Der Totaleindruck: Stil der Texte und Charakter der Sprachen. In Stil. Geschichte und Funktionen eines kulturwissenschaftlichen Diskurselements, ed. Hans Ulrich Gumbrecht and Karl Ludwig Pfeiffer, 169-188. Frankfurt/Main: Suhrkamp.

von Humboldt, Alexander. 1939. Briefe an Karl Gustav von Brinkmann. Ed. Albert Leitzmann. Leipzig.

- 1973. Die Jugendbriefe 1787-1799. Ed. Ilse Jahn and Fritz G. Lange. Berlin: Akademie-Verlag.

—. 1986a. Ansichten der Natur, mit wissenschaftlichen Erläuterungen. Nördlingen: Greno.

- 1986b. Reise auf dem Rio Magdalena, durch die Anden und Mexico. Teil I: Texte. Aus seinen Reisetagebüchern zusammengestellt und erläutert durch Margot Faak. Mit einer einleitenden Studie von Kurt-R. Biermann. Berlin: Akademie-Verlag.

-1991. Reise in die Äquinoktial-Gegenden des Nenen Kontinents. Mit Anmerkungen zum Text, einem Nachwort und zahlreichen zeitgenössischen 
Abbildungen sowie einem farbigen Bildteil. 2 vols. Ed. Ottmar Ette. Frankfurt/ Main: Insel Verlag.

. 2004. Ansichten der Kordilleren und Monumente der eingeborenen Völker Amerikas. Trans. Claudia Kalscheuer and Ed. Oliver Lubrich and Ottmar Ette. Frankfurt/Main: Eichborn Verlag.

- 2018. Das Buch der Begegnungen: Menschen - Kulturen - Geschichten aus den Amerikanischen Reisetagebüchern. Ed. and Trans. Ottmar Ette. Mit Originalzeichnungen Humboldts sowie historischen Landkarten und Zeittafeln. Munich: Manesse Verlag.

Open Access This chapter is licensed under the terms of the Creative Commons Attribution 4.0 International License (http://creativecommons.org/licenses/ by $/ 4.0 /$ ), which permits use, sharing, adaptation, distribution and reproduction in any medium or format, as long as you give appropriate credit to the original author(s) and the source, provide a link to the Creative Commons licence and indicate if changes were made.

The images or other third party material in this chapter are included in the chapter's Creative Commons licence, unless indicated otherwise in a credit line to the material. If material is not included in the chapter's Creative Commons licence and your intended use is not permitted by statutory regulation or exceeds the permitted use, you will need to obtain permission directly from the copyright holder.

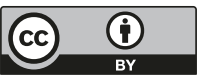

